\title{
総会の思い出
}

\section{Recollections of the JMLA Meetings of the Past}

東京女子医科大学図書館

梅 枝 軍 二*

昭和 2 年 (1927) に協会が官立医科大学附属図書館協 議会といら名称で創立されてから今年で50年を経過し， その記念すべき総会が順天堂大学を当番館として開催さ れることになった。

私は昭和 24 年第20回総会が名古屋大学で開催されたと き初めて出席, 以来昨年の鹿児島総会まで28年間にわた る総会に出席の幸運に恵まれ今日に至っている。その間 昭和32年には創立30周年記念式典をかねた第28回総会の 当番館を経験することができた。

記録によれば，創立当初の加盟館は僅かに 5 館，会議 出席者 8 名であったものが, 現在では加盟館85館, 総会 出席者は約 200 名の多きに達しているが，今後新設未加 盟の医歯大も何れは加盟し，100 館になるのも左程遠い ことではあるまいといわれている。

初めて出席した20回名大総会の記念写真を見ると，今 ではもう 1 名の現役での総会常連は見当らず，既に黄泉 の客となった何名かの先輩同僚の顔も見えて感慨一入， 私もまた現役とはいえない境遇にある。

この28年間の総会に出席し，じかに感得した記憶を辿 ると，なかには既に忘却の彼方に流れ去ったことなども 多いが，医学図書館に籍を置いたわが人生の 30 歳代から 60歳代の今日までの人生記録とともに，いろいろのこと が走馬灯のように浮んでくる。

協会の歴史的展望一正史については他に害かれる適 当な方もあろうかと思われるので割愛し，余り記録に出 ていないことの追憶にふけることにしよう。

総会出席の楽しみは年 1 回全国の同志が一堂に会して の協議であることはいうまでもないが，附随して次のよ うな楽しみが挙げられる。(1)開催地が未知の地であると

* Gunji UMEGAE : Tokyo Women's Medical College Library

（昭和52年 7 月 25 日受理）
き。従って，その近辺の観光をすること。(2)年 1 回総会: 常連の元気な顔を見ること。(3)司書が同じ宿に泊って胸 襟を開いて夜を徹しての談笑。(4)司書会食, 懇親会等。

司書会食は出席者の増加に伴ら経費等の関係から今で は姿を消し，最近出席の方はご存知ないと思うが，この 会食の発想は当番館の厚意によりプロフェッショナルな 司書の日頃の労をねぎららために催されたもので, 記憶 では26回德島総会頃に始まり37回札幌総会が最後であっ たように思う。また，この会食は徳島，群馬，東女など を除いては当番大学内で行われることが多かったが，そ こでは余り騒ぐ訳にも行かないので, 宿に帰っての二次 会, 三次会的な夜を徹しての語らいに発展するのが常で あった。宿では各室毎に入口に宿泊者の大学名と氏名が. 貼り出されていて, 誰が何処に泊っているかがすぐ判る 仕組。同じ道を歩む仲間同志の気安さから，らちくつろ いで歌や踊り，隠し芸が披露された。今でも強く記憶に 残っている方に德島での東大高杉司畫の尺八と三味線の 演奏がある。何れも相当の年季が入っていると見受けら れたが，とりわけ三味線では芸者が弾けずに困っていた のをすぐ取りあげて弾きこなしたのは見事であった。そ の後の総会にも高杉先輩はいつも尺八を携行しておられ た。

北大斉藤司書（故人）は大陸仕込みのダンスの名手で 会食, 二次会等では芸者と楽しく踊り, 踊れない私達を 羡しがらせたものである。

群馬での会食は今でも前橋一流の料亭の舞台つき部屋 で行ったが，名大小木曽司畫は芸者の三味線と唄に合わ せて踊りを披露, 前橋芸者の人気を一人占めしたもので あるが，それから先はどうなったか当番館の責任外で知、 るよしもない。これまた相当の年季もの，その後もたび たびの会食で踊りを披露するのが常であった。

東女での会食は今も新宿三光町の角にある水たき料理 の「玄海」であった。この時も歌や踊りでずい分騒いだ 
総 会 の思 い出 (梅枝)

が，私もついつられて見よう見ま社の下手な阿波踊りを 踊った。毎年司書会食で行われていた郷土みやげ品の交 換会はこの時から廃止されたといら。それは回を重ねる につれて新味がなくなるとともに，品物の選択も次第に 煩わしくなってきたことによるという。

この郷土みやげ品の交換会は廃止されたが, 総会のつ きものに各書店等から寄贈される記念品やみやげ品があ った。これには各社ネーム入りのタオル, 肌着, 靴下, ライター等々, 時には中身が男女別々のこともあり, 受 付をすまして会場に入ると各自の席に置いてあった。宿 の浴場で同じ肌着, 同じタオルで間違うこともあったよ らだ。このみやげ品のため宿に帰ってからの荷物整理が 大変で, ボール箱や紙佰が部屋に山積されることが多か った。ただ，いつる㑊われるのがカタログ，目録等の印 刷物で，重いしかさばるので特別のものを除いて紙屑と ともに捨てられる運命をたどった。

単に会食に限らず総会では, いつも一人や二人の人気 者がいるもので, 札幌木田橋司書や広島小坂司書(故人) などはなかなか朗らかな方で緊迫した会議の架気を笑い 唀う人柄であった。

然し，図書館人は概して真面目で，仕事の話を看に夜 を徹して飲んでいる方が多い。この代表的な方に山口木 村司書や福島丹野司書(何孔も故人), 現役中にも北南 汇何名かの顔が浮ぶが，私も梁更まで扣つき合いするこ とが多かった。

奈良総会での司書宿舎は檀原会館であったが，私はた またる金沢三宅司書と監查であったので翌日の会議に提 出する予算案の作成・修正に東大中里, 新潟中山, 医歯 大雨宮各理事と深更までかかったことがあったが，今か .ら思うと実にのんびりした時代であった。

次に, 観光・想親会では, 27回北大総会のため初めて 津軽海陕を渡り北海道の土を踏んだ時の印象は強烈であ った。この時の懇親会は月寒牧場での野外デンギスカン 料理, 観光は道東と道南の 2 班に分れ, 私は道南バス旅 行に参加した。札幌郊外の定山溪温泉を過ぎ中山峠, 洞 爺湖, 昭和新山の景観はすばらしく, 夜は登別温泉第一 滝本館泊り。ここの浴槽は当時日本一のスケールを誇り 週刊誌などで盛んに宣伝されていたが，入口こそ男女別 々であるが中は混浴，3以程の大きな浴槽に，も拈も拈 とたちこめる湯気は入浴者の視線をさえぎり, 混浴とい っても少しも扔かしくはなかった。誰だったか今はもら 名前を忘れたが, 翌朝のバス出発時間になっても一人だ 壮足りず案内の当番館を心配させたが，後で聞くところ
によれば浴槽で, もおも拈たる湯気の倩れ間の女性美を たっぷり観賞していたということであった。

28回群馬では30周年記念式典をかねて行われたが, 緹 方会長より余り派手にやると後に続く当番館がやりにく いので自肃するようにとのご指示があった。このことを 大学浫って上司に伝えたところ，何も前例にこだわら ず各館マイペースでやればよく，どうせ君の一生一回の 当番館だからできるだけ盛大にやれ，学部事務の全力を あげて協力するからといらことであったので私は上司の 指示に従った。受付案内は庶務, 会計は会計, 懇親会は 教務学事の各係長があたり，30周年記念行事の一つとし て行われた古医書展示会は慶応大鳥先生, 横浜石原先生 に依頼して集めたもので，中には日本に一点しかない貴 重なものもあったので夜は盗難防止に不寝番をおいた。 記念品の文鎮は私がデザインして館長, 会長に見てもら い, 制作は工学部に頼んで作ってもらったが，出席者だ けにしか配れなかった。な执, 当番館に対する協会の補 助金はこの時の総会で決り翌年より実施, 当時既設の医 大 (医学部) 46館全部の加盟が実現したのも群馬総会で あった。

留親会は，当時前橋にはホテル等の大きな施設はなく 市の公民館を借り，本場八木節を披露するとともに，前 橋芸者を人選してサービスにあたった。観光は伊香保, 草津温泉各一泊, 浅間山麓を巡って, 軽井沢解散であっ た。当時, 当番館を引受けると主任司書は約 $2 \sim 3 \mathrm{~kg}$ 忚 完全にやせるといわれ，私もまたそらであったが，最近 の当番館主任司書諸兄はどうであろうか。

続く29回名市では, 徳島, 北大, 群馬に負けじと経费 集めに大分努力したようで, 钼光は三河湾沿いの三谷温 泉富貴貫館宿泊, 30回九大は阿蘇観光, 31回東医, 36回 東女の烈親会場は椿山荘であった。今ではもう珍らしく もないが当時としては全くの “珍山荘”で抜群の会場, 東医原館長, 東女吉岡館長の出席者を歓待する熱意が偲 ばれた。

34回弘前での司書宿舎はスキー場で有名な大鰐温泉, 懇親会は弘前美人芸者を揃光ての銀行クラブ庭園での野 外パーティー, 観光は十和田湖周遊であった。林檎林が 連なる十和田八幡平国立公園の景観, 紅葉にはまだ早か ったが十和田湖巡り, 奥入瀬溪流, 酸ヶ湯温泉付近から の八甲田山の遠望, 道路脇に立つ積雪標識を見ては, か つての青森連隊の雪中遭難に思いを馳せるなど, 竹森主 任の総会にかけた心意気とともに忘れがたい思い出であ る。 
35回広島は, 比治山公園 ABCC (RERF) の見学, 牛 場会長の流暢な英語挨拶をききながらの市街展望, 名勝 縮景園, 平和記念公園を見て袮島神社詣で, 錦带橋下で の昼食で第った。終戦直後の焼野原と化した市街を見た 目に見事に復興した新生広島市, 日中事变から第二次大 戦にかけての数年間を南中国, 北ベトナム, 比島, イン ドネシア等の戦場を一兵士として過ごした身には，原爆 ドーム, 慰霊碑, 資料館の钼覧は複雑微妙な気持を抱か せた。

38回久留米, 40 回和歌山を最後に当番館による観光案
内は消隇した。今はもら誰でもが国内ばかりか外国萦で 気楽に出加る世の中, 宿舎のホテル化, 出席者の増加 等を考学ると当然のなりゆきといえる。思劣ば古き良き 時代だったといえよう。

それにしても，加盟館の增加にるかかわらず年々協議 題が少なくなるのはどうしたことか，従来ど打りの総会 のやり方は転換の時期に立ち至っているようだ。次代を 荷う若い世代の医学図書館人の活躍を期待して老兵は去 ってゆこう。

\section{$\diamond \quad$ 相互貸借マニュアル}

相互貸借業務必須のマニュアル。

日本医学図書館協会に和乩る申込の手続き(国内, 国外), 書誌事項の 確認，テレックスによる相互利用等を具体的に説明。

$$
\begin{array}{lr}
\text { サンプル 20枚 } & \text { 付録 : 各種資料案内 } \\
\text { ルーズ・リーフ } & \text { 1976発行 } 1977 \text { 改正 } \\
& ¥ 2,200
\end{array}
$$

\section{申込, 問合せ先}

113 東京都文京区弥生 $2-4-16$

$$
\text { 学会センタービル内 日本医学図書館協会 }
$$

TEL : 03-815-1942 振替 : 東京6-49585

取引銀行 : 三井銀行上野広小路支店 普通預金 (口座番号) 158-376 